
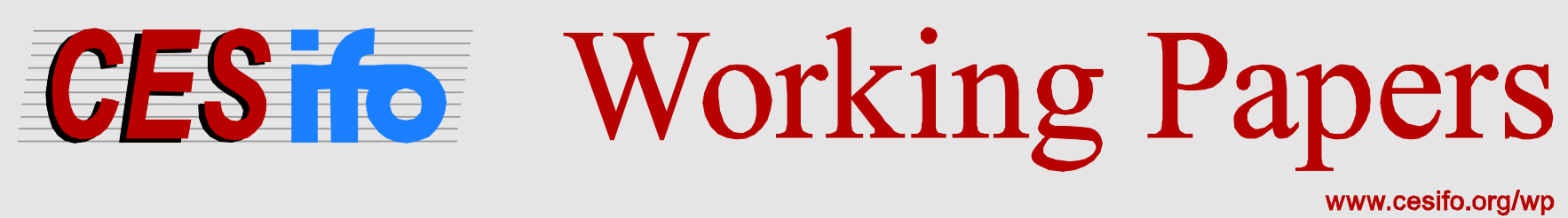

\title{
Policy Persistence and Rent Extraction
}

\author{
Silke Friedrich
}

\section{CESIFO WORKING PAPER NO. 4325 \\ CATEgory 2: Public CHOICE \\ JULY 2013}

Presented at CESifo Area Conference on Public Sector Economics, April 2012

An electronic version of the paper may be downloaded

- from the SSRN website:

- from the RePEc website:

- from the CESifo website:

www.SSRN.com

Www.RePEc.org

www.CESifo-group.org/wp

\section{CESifo}




\title{
Policy Persistence and Rent Extraction
}

\begin{abstract}
The existing literature has shown that special interest groups can have both growth enhancing and retarding effects on an economy. In either case it is always assumed that the nature of the special interest groups remains constant over time. The hypothesis of this paper is that a dynamic relationship exists between politicians and lobbyists. In the short run politicians may choose to support "projects" proposed to them by lobbies, because they yield clear economic benefits. However, governmental support may continue after these benefits have been exhausted, implying a cost to society and yielding private rents to the lobbies. A theoretical framework in which established and new lobbies overlap is developed to model the incentives a government might have to behave in a manner consistent with the hypothesis. In this structure despite the fact that politicians support projects from which all productive benefits have been extracted the voters can still rationally reelect them.
\end{abstract}

JEL-Code: D720.

Keywords: lobby, special interest, efficiency, elections.

Silke Friedrich

Ifo Institute - Leibniz-Institute

for Economic Research

at the University of Munich

Poschingerstraße 5

Germany - 81679 Munich

friedrich@ifo.de

February 15, 2012 


\section{Introduction}

Most economists agree that special interest groups can influence policy and the allocation of economic resources. ${ }^{1}$ The impact of special interest groups on economic well-being in a society can be positive or detrimental, depending on the circumstances. Two cases on opposite sides of this spectrum are the contributions of Putnam (1994) and Olson (1982). Putnam focuses on how special interest groups can build social capital. Analyzing data across Italian regions, he attributes the more effective governments and better economic performance of northern regions largely to their high levels of "civic engagement". He argues that special interest groups increase solidarity and cooperation, attributes necessary for the resolution of collective action problems. ${ }^{2}$ Olson, on the other hand, analyzes how special interest groups may limit growth possibilities due to personal (and political) self-interst. He observes that they have an incentive to lobby for socially inefficient policies which benefit themselves but are costly to society. In either case it is always assumed that the nature of the special interest groups remains constant over time.

The hypothesis of this paper is that opportunities for rent extraction for special interest groups can have elements of both the Putnam and Olson arguments as opportunities for rent extraction for special interest groups evolve over time. We argue that even if all projects are assumed to start off as being socially desirable, some projects will cease to be desirable at some point in the future. However, different projects become socially undesirable after different intervals of time. It then becomes possible that a government will support a project longer than is socially desirable.

There are numerous examples of government agencies that have been accused of supporting certain projects proposed by lobby groups beyond the point at which all productive rents have been exhausted. A recent example of such a project is the US F-22 Raptor fighter jet. It was developed in the 1980s to shoot down the latest Soviet combat planes. Even today, the Raptor is described as technological marvel, and at over a quarter of a billion dollars per plane it is the most expensive fighter jet ever built. 187 Raptors are in service of the United States Air Force today. ${ }^{3}$ Hence, as the New York Times put it, "Americans can now feel reassured that if the Soviet Union ever springs back to life, restarts the Cold War and designs a new MIG fighter more advanced than anything now in the skies, the United States Air Force is ready." 4 Unfortunately, today's foes are very different from those the Raptor was designed to fight. In Iraq and Afghanistan, the US Army is fighting a highly motivated, low-tech enemy who blend in and out of urban civilian populations or

\footnotetext{
${ }^{1}$ Special interest groups can contribute to a policy maker's political support by making campaign contributions or by providing information. A rational policy maker takes the effect of these contributions into account for making policy decisions. See, for example, Peltzman (1976), Hillman (1982), Becker (1983), Grossman and Helpman (1994), Tullock (1983, 1989), and Crew $(1988,1990)$

2 "Civic engagement", according to Putnam, includes all groups that form in a society because their members share a common interest. This definition includes community level groups (for example bird watching groups) as well as organizations on a national level (for example trade unions).

${ }^{3}$ Source: Airforce-technology.com, accessed on 06/21/2011

${ }^{4}$ Source: New York Times: http://query.nytimes.com/gst/fullpage.html?res=9B0DE6D9133DF93AA15753C1A9629C8B63, accessed on $06 / 21 / 2011$
} 
hide in remote mountain areas and caves. The Raptor is useless in such an environment, and hence, the F-22 has never been used in a war. In July 2009, the US Senate stopped a bill that would have authorized funds for an additional seven Raptors. President Obama praised the Senate's decision, saying that any money spent on the fighter was an "inexcusable waste". 5

Another example of a military project that was once beneficial but has been continued too long is the German Leopard 2 tank, which has been promoted by the German defense industry. ${ }^{6}$ This tank was developed during the Cold War to fight an enemy approaching Germany across the North German plain. But even the latest version of the Leopard 2 is too big to be useful for other actions. In fact, the Bundeswehr does not even have a cargo plane large enough to transport the Leopard 2. The latest version has been in active service since 2001. In 2004, the German Bundeswehr still had 1552 battle tanks of the type Leopard 2 waiting for an enemy to attack. ${ }^{7}$ Between then and 2008, the Bundeswehr reduced the number of active Leopard 2 s to $400 .^{8}$

There is no doubt that the F-22 Raptor and the Leopard 2 were good investments - good "projects" - during the Cold War. But support for these projects continued after their purpose for existence disappeared. ${ }^{9}$

Agricultural subsidies in the US and in Europe provide similar examples. Franklin D. Roosevelt introduced farm subsidies in the US in the 1930s in response to a massive farm depression and the effects of a concurrent drought. These were, according to Secretary of Agriculture Henry Wallace, "a temporary solution to deal with an emergency". In Europe, agricultural subsidies started after WW2 within the independent European nations. The EU took over these national programs in the 1950s and 1960s. The initial reason for these programs in Europe was to encourage increased food production. After the EU took over, the programs were continued to ensure that European countries did not come into conflict over scarce foodstuffs. Today neither of these reasons hold yet the programs remain in place and prices received by farmers in the EU and agricultural producer prices in the US are $33 \%$ and $15 \%$ respectively above world levels. ${ }^{10}$ There is evidence that the EU and the US would be better off without agricultural protection. ${ }^{11}$

The examples above suggest that interest groups initially exist to communicate to a government the existence of opportunities to create productive benefits that initially increase social welfare. However, once the social benefits have been fully extracted, the special interest groups may switch

\footnotetext{
${ }^{5}$ Source: New York Times: http://www.nytimes.com/2009/07/22/business/22defense.html, accessed on $06 / 21 / 2011$

${ }^{6}$ See Arno Neuber, 2009, "Zum Barbecue mit Ruestungsbossen", IMI-Magazin, for an overview of the close relationship between the defense industry and the parliamentary defense committee in Germany.

${ }^{7}$ Source: Otfried Nassauer for the Berlin Information Center for Transatlantic Security, October 302004.

${ }^{8}$ Source: Das Schwarze Barett: Ausruestung der Panzertruppe im "Heer 2010", 32/2004, p.23

${ }^{9}$ In the framework of a cost-benefit analysis of such projects, these are cases in which the benefit declines over time. For a precise analysis in such a framework it would be necessary to further examine the cost structure of the projects. See Mishan and Quah (2007).

${ }^{10}$ The base year for these statistics is 2001. For more detail see Tokarick (2005)

${ }^{11}$ See for example Anderson (1998), Tokarick (2005)
} 
to pure rent extraction, to the detriment of social welfare. ${ }^{12}$

This paper is related to the classical question in public choice of whether political markets promote efficient policy choices. The literature on this topic is divided in two main opposing schools of thought. In the Virginia school of political economy it is argued that political markets tend to produce inefficient policy outcomes (e.g., Olson 1982), mainly because valuable resources are employed in wasteful rent seeking activities (e.g., Tullock 1983, 1989, Crew 1988). Scholars of the Chicago school of political economy argue that political markets produce efficient policy outcomes, since government regulations that survive in the political process tend to be relatively efficient (e.g., Becker 1983). ${ }^{13}$ A main difference between these schools lies in the definition of efficiency (Crew 1988, 1990). Crew (1990) criticizes Becker (1983) saying that "one cannot sustain the argument that the existing functions of government are the best we can do given exogenously determined constraints if the constraints in question are in fact endogenously determined in the model. It is a tautology that largely rationalizes the status quo". Aidt (2003) supports Crew's reasoning by extending Becker's model. He endogenizes political participation with the results that political outcomes are no longer necessarily efficient and competition is not a sufficient condition for efficient policy outcomes anymore.

Whenever the presence of lobby groups leads to Pareto-dominated policies, the question arises of why voters tolerate such policy choices. The existing literature has focused mainly on one side of the answer to this question, on the explanation for inefficient short term biases in public spending. ${ }^{14}$ Coate and Morris (1999) model how special interest groups can "buy" policy decisions from politicians, but the politician is not then re-elected. They suggest that voters will not support policies that provide temporary efficiency improvements if they cannot control how long a costly policy persists once it is introduced. Aidt and Dutta (2007) find that growth in government eventually leads to a bias in public expenditure towards short-term projects and argue that this can be explained by a desire on the part of the electorate to check frequently on the performance of politicians.

The anecdotal evidence of the defense and agricultural industries in Europe and in the US discussed above suggests that these projects were not inefficient investments when they were started. But even though they were initially socially beneficial, government support for these projects continued after their purpose for existence disappeared. The model introduced in this paper displays

\footnotetext{
${ }^{12}$ The examples above suggest that the presence of special interest groups can be valuable to welfare maximizing governments because they can provide information about productive projects. However, not all public projects are advertised by special interest groups. But for the theoretical approach to explain the anecdotal evidence, this study focuses on the cases in which special interest groups have more information about rent generating projects than governments.

${ }^{13}$ Even in case policy outcomes are efficient, there are winners and losers if opposing parties try to push their interests forward. The question then is why the losers accept new policies. See Begovic and Paunovic (2011) for an example of this strand of the literature.

${ }^{14}$ Cassing (1991) provides a model of "policy hysteresis", but in this framework there is no punishment for the politicians if they cater to special interests.
} 
an equilibrium which rationalizes these observations. The purpose of this paper is not to give another explanation of why inefficient projects are introduced, but to introduce a rationale for why projects can persist beyond a point where they have become inefficient. Hence, we develop a model that allows to explain long term biases in public spending. Projects can be funded inefficiently long for three reasons according to this model. The first one is that lame-duck politicians have an incentive to keep inefficient projects alive in return for rents from the lobbies. Secondly, newly elected politicians, despite the electoral consequences, may also choose to continue inefficient projects in exchange for "contributions" from the lobby groups. A third explanation for a long term bias in public spending is given for an environment in which it is not possible to determine up front how long projects are socially desirable. In the case of such information asymmetries, even good politicians may be rationally re-elected if they pursue policies that persist "too long", because if they did not then the quality of the pool of new projects would deteriorate. This deterioration arises because of an adverse selection effect under which the lobbies offering the projects that are socially most beneficial would not join the pool because of their dependence on future government support. ${ }^{15}$

Following Besley (2006), there are two types of politicians in this model; good and bad ones. The bad politicians purely maximize private rents and the good types also care about voter welfare. This is in contrast to the public choice view that individuals are generally self-interested and therefore, as Aidt and Dutta (2007) put it, a benevolent politician is "a myth". With the notion of good and bad politicians we show that even if there are differences in the politicians' utility functions

(e.g., that some politicians are more idealistic or more altruistic than others) there are still cases in which these stylized "good" politicians would choose to support interest groups inefficiently long and remain in office.

The simple model developed in this paper follows the tradition of formal political economy models; we intend to develop a systematic understanding of complex social phenomena and abstract from much of the detail.

\section{A model of lobbying}

\section{$2.1 \quad$ Players}

The economy consists of an electorate, a set of politicians, and a set of lobbying firms. In each period the electorate must choose a politician to act as the government, the politician elected must in turn choose which productive projects to pursue from a set of alternatives offered to them by the lobbying firms. The electorate are infinitely lived. Each lobbying firm lives for at most two

\footnotetext{
${ }^{15}$ The difference between the adverse selection effect here and the one developed by Le Breton and Salanie (2003) is that, according to the latter, the reason for adverse selection is direct competition between the lobbies, whereas in the model developed in this paper, adverse selection is caused by information asymmetries between the lobbies and the government.
} 
periods, and offers a single potential project to the government in its first period of life. Politicians may hold office for a maximum of two periods. In every period there are potentially present in the economy "old" lobbies, $(O)$, in the second period of their lives, and "young" lobbies, $(Y)$, in their first. Hence the life of a lobby may coincide with the period in office of a single politician or overlap the terms of two.

There are two different types of lobby groups in the economy: low, $(L)$, and high, $(H)$, which occur in the proportions $\alpha$ and $1-\alpha$ respectively. High type lobbies promote projects that are socially productive for two periods. Low type lobbies promote projects that are only socially productive for a single period. It is therefore natural to assume that the fixed up-front costs of a project are higher for high types. This might be due to something as simple as the fact that the buildings and plant required to continue production of a product for several years need to more durable, longer-lived, and therefore more costly that those required only to last for a short time span. ${ }^{16}$

Following Besley (2006) there are two types of politicians who may form the government; good, $(G)$, and bad, $(B)$, who occur in the population of potential politicians with frequencies $\pi$ and $1-\pi$ respectively. Good politicians act in the interests of voters. Bad politicians maximize their own private rents. The electorate choose a politician to select projects on their behalf. In periods in which the incumbent is ineligible for re-election this takes the form of selecting a random replacement from the pool of potential candidates. In periods where the incumbent is eligible for re-election the selection is determined by majority voting.

There is a pool of potential lobbies in the polity. In each period, every potential lobby must decide whether or not to become active and join the pool of lobbies from which the government selects its projects.

\subsection{Timing and information structure}

The timing of the agents' decisions is illustrated in Figure 1. In any period the sequence of events is as follows: First lobbies of either type must choose whether to join the pool from which projects are selected. Next the electorate choose the politician to run the government for that period. If an incumbent is eligible for re-election the electorate base their voting decisions on observations of the politician's previous choices and the payoffs they, the electorate, enjoyed. If the incumbent is ineligible the politician is selected by random draw. The selected politician then simultaneously draws a potential project to realize from the pool promoted by the lobbies, and whether or not to continue supporting any previously selected projects. ${ }^{17}$

\footnotetext{
${ }^{16}$ Relaxing this assumption would not change the equilibrium of the baseline model. But it would alter the results of the extension to the baseline model: even good governments would be more likely to support low type lobbies inefficiently long, and there would not be an adverse selection effect.

${ }^{17}$ There is a large body of literature that deals with competition between lobby groups, the resulting rent-seeking costs, and the process of how governments choose one lobby group over another. Following Potters and Van Winden (1992) it is assumed that the informational value of a lobby's signal to the government about its type is not the
} 


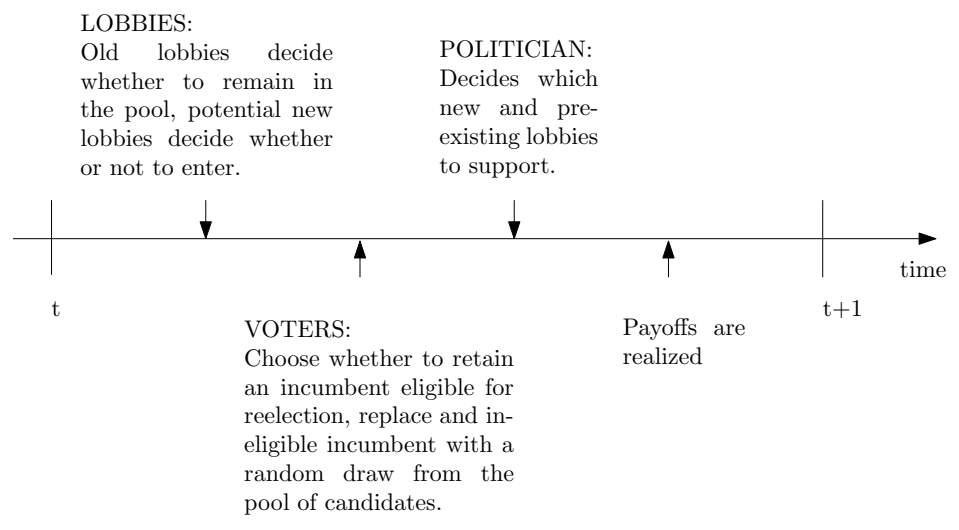

Figure 1: Timing

The politician knows the type of the old project but only learns the type of the new project after it is selected. The projects, potentially both new and old, are realized and the electorate receive their payoffs. The game repeats in the next period. For simplicity we shall subsequently assume that the politician selects at most one new project per period, that all agents discount the future using the common discount factor $\beta<1$, and are risk neutral.

\subsection{Payoffs}

\subsubsection{Politicians}

Politicians of both types receive a combination of wage and ego rent from holding office denoted $E$. Bad politicians may also in principle receive side-payments of $R$ from any lobbies they support in a period. Good politicians also care about the net social benefits enjoyed by the electorate $X$. Hence, a polician's payoff per period can be written as

$$
P(j)= \begin{cases}E+R & \text { if the politician is bad } \\ E+X & \text { if the politician is good }\end{cases}
$$

where $j=G, B$ is used to indicate the politician type.

\subsubsection{Lobbies}

Lobbies may be young or old and of high or low type (their members are also assumed to be voters and to receive any payments given to voters). All lobby types supported by the government receive a per-period subsidy of $k$. The lobbies' costs depend upon their type and are denoted $a_{s}$

content of the message sent but the resources spent on sending the message. Since all lobbies have the same amount of initial resources in this model, they cannot signal their type to the government. 
where $s \epsilon\{L, H\}$. The payoffs to the lobbies depend on the type of politician $(G, B)$ they face. The incremental payoffs to a young lobby in the first period if the politician is good may be written

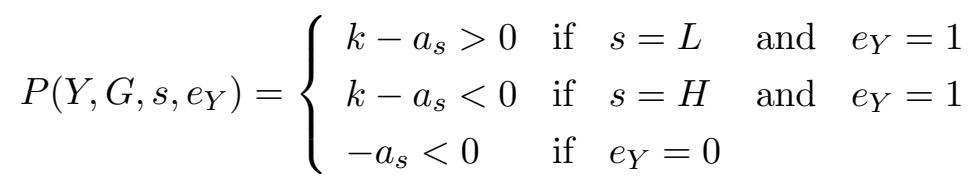

Where $e_{Y}$ is an indicator variable taking the value 1 if the young lobby receives government support and 0 otherwise. The first-period payoff from lobbying is positive if the lobby is a low type and is negative if the lobby is a high type, reflecting the high types greater up-front fixed costs. This implies that a high type lobby will not join the pool if it cannot obtain support in its second period.

The incremental payoffs to a young lobby in the first period if the politician is bad may be written

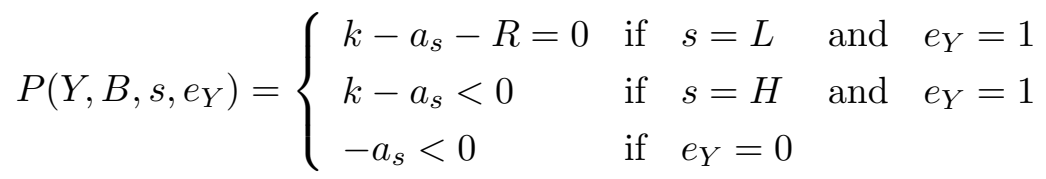

Hence, bad politicians extract maximum private rents from the lobbies, which implies that the payoff of young, low type lobbies is zero if a bad politician is in office. ${ }^{18}$

If a good politician is in office, the incremental payoff for an old lobby $O$ at time $t$ is written

$$
P\left(O, G, e_{O}\right)=\left\{\begin{array}{lll}
k & \text { if } & e_{O}=1 \\
0 & \text { if } & e_{O}=0
\end{array}\right.
$$

where $k$ is interpreted as before and $e_{O}$ is an indicator variable taking the value 1 if the old lobby receives government support and 0 otherwise.

If a bad politician is in office, the incremental payoff for an old lobby $O$ at time $t$ is written

$$
P\left(O, B, e_{O}\right)= \begin{cases}k-R=0 & \text { if } e_{O}=1 \\ 0 & \text { if } e_{O}=0\end{cases}
$$

where $R$ is again a private side-payment from the lobby to the politician.

\subsubsection{Electorate}

The electorate receive a per-person net social benefit of $x$ from all projects that are socially productive. This includes the projects adopted from all young lobbies plus the projects of any remaining old high type lobbies. Should the government support an old low type lobby this yields a net social

\footnotetext{
${ }^{18}$ It is assumed that bad politicians cannot make the lobbies borrow against future earnings.
} 
cost to the electorate. ${ }^{19}$

Hence, in every period, the voters receive a payoff of

$$
X=x\left(e_{Y}\right)+x_{s_{O}}\left(e_{O}\right)
$$

where

$$
x\left(e_{Y}\right)\left\{\begin{array}{lll}
>0 & \text { if } & e_{Y}=1 \\
=0 & \text { if } & e_{Y}=0
\end{array}\right.
$$

where no identifier is required for the payoffs received by the electorate from young types, and

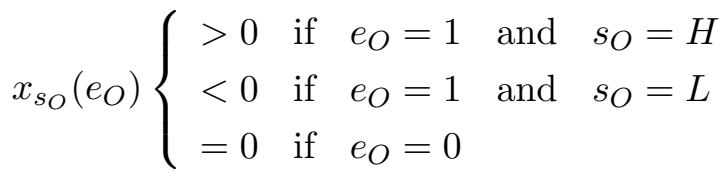

This simply spells out that only high type projects are socially productive in their second period of life.

\subsection{Equilibrium}

The equilibrium consists of a strategy for each player defined on the appropriate action space, plus beliefs for each player that are updated appropriately using Bayes rule such that the conditions for a perfect Bayesian equilibrium are satisfied. In each period nature moves first and selects which potential lobbies are low and high types with probabilities $\alpha$ and $1-\alpha$. These probabilities are known to all the players but only the potential lobbies know their own type. Each type of lobby has a plan that involves first whether or not to enter the initial pool from which the politician makes a selection, and then if selected whether to lobby for one or two periods. As with lobbies nature moves first in the selection of a politician's type, choosing good and bad types with probabilities $\pi$ and $1-\pi$ respectively. Again these probabilities are known to all the players, but only the politicians observe their own type. Politicians of either type formulate a plan involving the random choice of a new young lobby from the pool, then whether or not to support lobbies of either type in either period and whether or not to demand any side-payments. The electorate know the values of $\pi$ and $\alpha$ and update their beliefs appropriately after observing their own per-period payoffs. In periods where an incumbent politician is eligible they choose whether or not to re-elect them, based on the politician's previous choices and the payoffs they, the electorate, enjoyed. It is assumed that voters can commit to re-elect the politician if they receive at least $X=x\left(e_{Y}\right)+x_{s_{O}}\left(e_{O}\right) \geq x\left(e_{Y}\right)$, which

\footnotetext{
${ }^{19}$ All projects are financed through taxes. Hence, the payoffs voters receive are the benefits from the projects minus the tax imposed to finance them.
} 
is the payoff they receive if a good politician is in office, depending on the old lobby's type. ${ }^{20}$ In periods when an incumbent is not eligible for re-election a new politician is randomly selected from the pool. Hence,

Proposition 1 Voters do not re-elect politicians who support old low type lobbies in their first period in office.

The proof of this and all subsequent propositions may be found in the appendix.

Given that politicians cannot be re-elected after their second period in office, the agents' optimal strategies can be found by using backward induction. ${ }^{21}$

Suppose that the incumbent is a good type - by definition they do not demand side payments and do not support old low type lobbies as this reduces the net social benefits enjoyed by the electorate. ${ }^{22}$ They do support all young lobbies and high types in the second period of the type's life. Alternatively, suppose the incumbent is a bad type - in their second period in office they demand side-payments in return for supporting either high or low type lobbies. In the first period a bad politician is in office they choose between mimicking the good type, which we will refer to as "pooling" behavior, or "separating" from the good type. If they choose to pool, for purposes of re-election and the consequent future payments, they must support only old high types. If they separate they support both old high and low types, they are revealed to be bad and are not re-elected.

Bad politicians extract the maximal private rent from the lobbies. Hence, when they demand side-payments, they require $R(B, i, j)$ from each active lobby, depending both on whether the lobby is young or old $(i=\{Y, O\})$ and on whether it is a high type or a low type $(j=\{H, L\})$. The side-payments from low type lobbies are written

$$
R(B, i, L)= \begin{cases}k-a_{L} & \text { if } i=Y \\ k & \text { if } i=O\end{cases}
$$

And the side payments bad politicians receive from high type lobbies are

\footnotetext{
${ }^{20}$ The assumption that voters can commit to a re-election rule is used for a similar purpose as the set-up of the model with good and bad politicians. It also strengthens the point that inefficient long term biases can exist even under the most preferable conditions. The re-election rule makes sure that elections set strong incentives for politicians (Gersbach 2004). In this model, the only equilibrium affected by the re-election rule is the pooling equilibrium in the baseline model.

${ }^{21}$ Having term limits does affect policy choices, as empirically shown by Besley and Case (1995). In this model, the absence of term limits would exclude the possibility of lame duck politicians. This would be welfare improving in this framework since bad politicians would be more likely to pool with good types. Term limits are also an important determinant of the social cost of rent-seeking. Aidt and Hillman (2008) show that rent-seeking is discouraged if policy makers cannot protect future rents.

${ }^{22}$ This results from the active lobbies being part of the electorate, as described above.
} 


$$
R(B, i, H)= \begin{cases}0 & \text { if } i=Y \\ 2 k-a_{H} & \text { if } i=O\end{cases}
$$

We may now characterize when bad politicians engage in pooling or separating behavior in their first periods in office by comparing the appropriate expected payoffs. Recalling that both good and bad politicians support old high type lobbies and hence pooling is automatic, we need only give conditions for pooling and separating when the old lobby is a low type, viz.

Proposition 2 (1) If the old lobby in period 1 is a low type and the young lobby is a high type, then a bad politician chooses to pool if $E \geq \frac{k}{\beta}-\left(2 k-a_{H}\right)-\alpha\left(k-a_{L}\right)$ (2) If both the young and the old lobby in period 1 are low types, then a bad politician pools if $E \geq\left(\frac{1-\alpha \beta}{\beta}\right)\left(k-a_{L}\right)+k\left(\frac{1-\beta}{\beta}\right)$.

These pooling conditions imply that the probability that a bad politician pools in period 1 increases in the politician's ego rent $E$. This follows because pooling ensures re-election and the receipt of the second period ego rent. Bad politicians are also more likely to pool if they are more patient, i.e., when the discount factor $\beta$ is high, simply because they then place a higher value on the second period payoffs associated with re-election. A high $\alpha$, i.e., a large share of low type lobbies in the pool of potential lobbies also increases the probability that a bad politician pools, because a high share of low type lobbies increases the expected payoff to the politician in the second period.

The pooling condition in the case that the young lobby is a low type is more restrictive if $k-a_{L}+\beta\left(k-a_{H}\right)>0$, i.e., if the payoff a low type lobby receives in its first period is larger than the discounted loss of a high type lobby in its first period.

Both low and high type lobbies always join the pool of lobbies. Low type lobbies are able to cover their costs in the first period and high type lobbies know that any type of politician keeps supporting them in their second period.

Proposition 3 Pooling is socially desirable.

This follows immediately from noting that a side payment is just a transfer from one agent to another as is financial support from a government to a lobby of any type. Hence the social desirability of pooling hinges on the spillovers generated by lobbies. If there is an old low type and young high type then with separating behavior old low type lobbies are supported by bad politicians giving negative spillovers; with pooling these are avoided. When there is an old low type and young low type then there will be negative spillovers in the current period under separating behavior and potentially negative spillovers in the next period if a new bad type politician replaces the current bad one. Under pooling behavior there will only be negative externalities in the next period, hence both discounting and the possibility of electing a new bad politician make 
this socially superior.

The equilibrium strategies can be summarized as follows. Bad politicians pool with good ones if the conditions of Proposition 2 hold. This tends to occur if the discount factor $\beta$ and the share of low type lobbies $\alpha$ are high. Bad politicians are re-elected in this case. If bad politicians choose to separate from good ones, they reveal their types and as a consequence, they are not re-elected. But if there are no re-election concerns, which is the case in a politician's second period, then bad politicians support old low type lobbies if they picked a low type from the pool in period 1 . The politicians' actions only differ with respect to their decision to continue old projects. All politicians choose to support young lobbies in equilibrium and both types of lobbies join the pool.

The model provides two explanations for the problem initially discussed, that is, lobbies that are no longer socially desirable continue to receive government support. First, old low type lobbies may receive support from lame-duck politicians in return for side-payments. Second, young bad-type politicians may choose to separate from good-type ones so as to receive side payments from current old low type lobbies. Applying this model to the decisions of the US and European governments to continue agricultural subsidies would suggest that only lame duck or bad politicians have an incentive to continue these subsidies after their purpose has become obsolete.

But this model is too simplistic to explore such issues as which lobbies choose to enter the pool of potential lobbies, and what allows bad-type politicians to engage in socially undesirable support for lobbies in successive periods yet remain in office.

This last question is of particular interest with respect to term limit effects. The behavior of a lame duck politician is driven by term limits. In the next section we explain situations in which politicians engage in undesirable support for lobbies and yet are re-elected, a result that is independent of term limits.

To investigate these issues we next reduce the information available to politicians, specifically we assume a lobby's type is no longer directly observable by a politician. This allows both good and bad politicians to potentially support old low type lobbies. But this implies that the electorate cannot perfectly deduce a politicians type from observing payoffs, potentially allowing bad types that support old low type lobbies to gain re-election.

\section{$3 \quad$ The model with unobservable lobby types}

In the baseline specification above it was assumed that a politician knows a lobby's type as soon as the latter is picked from the pool of potential lobbies. In the following extension I consider the case in which the lobbies' types are no longer observable by the politician. This is important because in reality it is often difficult for governments to foresee the exact impact a project has on voter welfare. For example, given that the relationship of a country to its potential enemies does not 
change discretely, it is questionable whether national governments can determine how long their military projects are beneficial. Hence, in the following, we modify the model above by assuming that politicians cannot distinguish between high and low type lobbies until after the projects are completed.

\subsection{Equilibrium}

As in the baseline specification, the agents' optimal strategies can be found by using backward induction. Good politicians support all young lobbies, and they would like to support old high types but not old low types. Since they cannot distinguish between the lobby types, politicians support old lobbies as long as this maximizes expected voter welfare. The necessary condition for supporting old and young lobbies is given by Proposition 4.

Proposition 4 Good politicians support both lobby types as long as $\alpha \leq \frac{1}{2}$.

This condition implies that good politicians will support all old lobbies if there are at least as many high type lobbies as low type lobbies in the pool of potential lobbies.

Alternatively, suppose the incumbent is a bad type. In their second period in office they demand side-payments in return for supporting either high or low type lobbies. In the first period a bad politician is in office they choose between pooling with or separating from the good types. Pooling is automatic if $\alpha \leq \frac{1}{2}$, i.e., if good politicians support both types of lobbies. If $\alpha>\frac{1}{2}$, bad politicians can choose to pool and only support young lobbies for purposes of re-election and the consequent future payments. If they separate and support both young and old lobbies, they are revealed to be bad types and are not re-elected. Bad politicians engage in pooling behavior in their first periods in office if the condition in Proposition 5 holds.

Proposition 5 Bad politicians pool with good ones if $E \geq\left(\frac{1}{\beta}-2\right) \alpha k+\left(\frac{1}{\beta}-1\right)(1-\alpha)(2 k-$ $\left.a_{H}\right)+\alpha a_{L}$.

This implies that bad politicians are more likely to pool if the fraction of low type lobbies in the pool of potential lobbies is small since this implies that the probability of receiving side payments from old low type lobbies in the politician's first period is small. Bad politicians are also more likely to pool if they are more patient, i.e., when the discount factor $\beta$ is high, simply because they then place a higher value on the second period payoffs associated with re-election. The effect of the per-period subsidy $k$ on a bad politician's decision about whether or not to pool with good types is positive as long as $\alpha \leq(1-\beta) 2$, which implies that a high $k$ makes pooling more likely if the discount factor is sufficiently high and the share of low types $\alpha$ is sufficiently small. This again hinges on the politician's valuation of future payoffs.

Unlike in the baseline model, not all lobbies always join the pool of potential lobbies. High type lobbies only join if the fraction of high type lobbies is sufficiently large, more precisely, when Proposition 6 holds. 
Proposition 6 High type lobbies join the pool as long as $\alpha \leq \frac{1}{2}$.

This is the case because high type lobbies only join the pool if they are supported by good politicians. The reason for this is that the expected payoff of high type lobbies is negative if only bad politicians support them in the lobbies' second period. If high type lobbies do not join the pool of potential lobbies, then bad politicians pool if

$$
E>k\left(\frac{1}{\beta}-2\right)+a_{L}
$$

which implies that pooling is more likely if there are only low type lobbies in the pool.

Comparing the pooling conditions of this extension to the ones of the baseline model shows that the latter are more restrictive.

Proposition 7 Pooling is more likely in the model with unobservable lobby types than it is in the baseline model.

In the baseline model, the only uncertainty about a bad politician's payoff in the second period is the type of the new lobby in period 2. In the extension to this model, politicians have no information about the two lobbies they can choose to support. This makes separating behavior more risky and therefore pooling more attractive.

If politicians cannot observe the types of the lobbies, high type lobbies would like to change the information structure and signal their type to the government - in which case they would be supported for sure. Following Potters (1992) it can be assumed that the informational value of the signal is not the content of the message sent but the resources spent on sending the message. Since all potential lobbies in the pool are assumed to have the same amount of resources, low type lobbies are able to signal the exact same way as high types. This implies that high types cannot distinguish themselves from low types by signaling.

As in the baseline model, pooling is socially desirable if politicians cannot observe the lobbies' type.

Proposition 8 Pooling is socially desirable.

The social desirability of pooling hinges on the expected spillovers generated by lobbies, just as in the baseline model. Whether bad politicians pool with or separate from good types, the expected voter payoff is always higher in the baseline model. The reason for this is that politicians have more information to base their decisions on in the baseline model.

The equilibrium strategies can be summarized as follows. Bad politicians pool with good ones if $\alpha \geq \frac{1}{2}$ and if the condition in Proposition 5 holds, which tends to occur if the share of low type 
lobbies is high. Bad politicians are re-elected in this case. If bad politicians choose to separate from good ones, they reveal their types, and as a consequence they are not re-elected. But if there are no re-election concerns, which is the case in a politician's second period, then bad politicians always support old lobbies. The politicians' actions only differ with respect to their decisions to continue old projects. All politicians choose to support young lobbies in equilibrium. Low type lobbies always join the pool of lobbies, and high types only join if good politicians support them in their, the lobbies', second period, i.e., if $\alpha \geq \frac{1}{2}$.

The model with unobservable lobby types provides the same two explanations for the problem initially discussed as the baseline model. First, old low type lobbies may receive support from lame-duck politicians in return for side-payments. Second young bad-type politicians may choose to separate from good-type ones so as to receive side payments from current old low type lobbies. In addition, this specification addresses circumstances under which some lobbies are not willing to enter the pool of potential lobbies. This specification shows that if a politician cannot clearly observe a lobby's type, there are circumstances under which even a good politician provides support for low type lobbies in the second period. This gives bad-type politicians an additional opportunity to engage in socially undesirable support of lobbies in successive periods yet remain in office. Hence, if politicians cannot clearly observe a lobby's type, then there are cases in which voters are willing to accept a long run bias in public policies, i.e., re-elect politicians even if they fear that some projects are supported inefficiently long.

Applying this model to the decision of the US government to continue funding the F-22 Raptor would suggest the following. At the time when the project was started it was very difficult to foresee the end of the Cold War. Hence, even good politicians might have continued the funding for the Raptor, because of the limited information available to them.

\section{Conclusions}

The hypothesis of this paper is that a dynamic relationship exists between politicians and lobbyists. Anecdotal evidence of support for military projects and agricultural subsidies suggest that special interest groups initially exist to communicate to a government the existence of opportunities to create productive benefits. Such lobbying activities may initially increase social welfare. However, once these benefits from an opportunity have been fully extracted the special interest groups may switch to pure rent extraction behavior, to the detriment of social welfare.

A theoretical framework is developed in which established ("old") and new ("young") lobbies overlap. There are two different types of lobby groups in the economy: low, and high. High type lobbies promote projects that are socially productive for two periods, and low type lobbies promote projects that are only socially productive for a single period.

A baseline specification provides two answers to the question: "why do politicians choose to 
support lobbies for an inefficiently long period of time?" First, lobbies whose social benefits have been exhausted (old low type lobbies) may receive support in a pooling equilibrium from lameduck politicians in return for side-payments. Since bad politicians maximize private rents and not welfare, they have an incentive to support such lobbies for as long as possible. Second, bad-type politicians may choose to separate from good-type ones (welfare-maximizers) so as to receive side payments from current old low type lobbies. Bad politicians are not re-elected if they engage in separating behavior.

In an extension to the model, politicians are not able to observe the types of the lobbies seeking support. This specification describes circumstances under which some lobbies are not willing to enter the pool of potential lobbies. This is the case if the lobbies cannot be assured of future support. Also, there are circumstances under which even a good politician chooses to support low type lobbies inefficiently long and is re-elected anyways because if they did not then the quality of the pool of new projects would deteriorate.

In the equilibria of both the baseline model and its extension, pooling is socially desirable, because it implies that bad politicians behave the same way as good ones. Pooling is also more likely if the discount factor is high, because the more patient politicians are, the more important is their expected future income or their decisions today, and the more likely they are to forgo short term rents for future payoffs. Hence, the more patient bad politicians are, the more likely it is that they make choices that are aligned with the voters' preferences. The two model specifications differ according to the level of transparency. In the baseline model, the government has enough information to make choices that are aligned with the voters' preferences. Hence, voters can punish the government if it does not behave according to their preferences. If the government does not know the type of the lobbies, and this is known by the voters, then the latter accept a long-term bias in public spending. ${ }^{23}$

The model developed in this paper is intended to give a theoretic explanation of why governments support lobbies beyond the point at which all productive benefits have been extracted - and are still rationally re-elected. The reasons why lobbies are supported inefficiently long can explain why some industries such as the agricultural and the defense industry have been able to receive continued support from US and European governments in recent decades, even though it has been questionable whether continued funding is beneficial for a country as a whole. ${ }^{24}$

\footnotetext{
${ }^{23}$ If the voters do not observe their payoff until after they have to choose whether or not to re-elect the government, then the equilibrium suggests that the voters only re-elect the government if it supports young lobbies. Hence, they accept a short term bias of public spending, which is similar to what Coate and Morris (1999) find.

${ }^{24}$ This framework could be used to explain principal problems in a broader settings, for example in outsourcing relationships. But in such cases it would be useful to endogenize the relationship between the principal and the agent. See for example Bhimani et al. (2010).
} 


\section{Appendix}

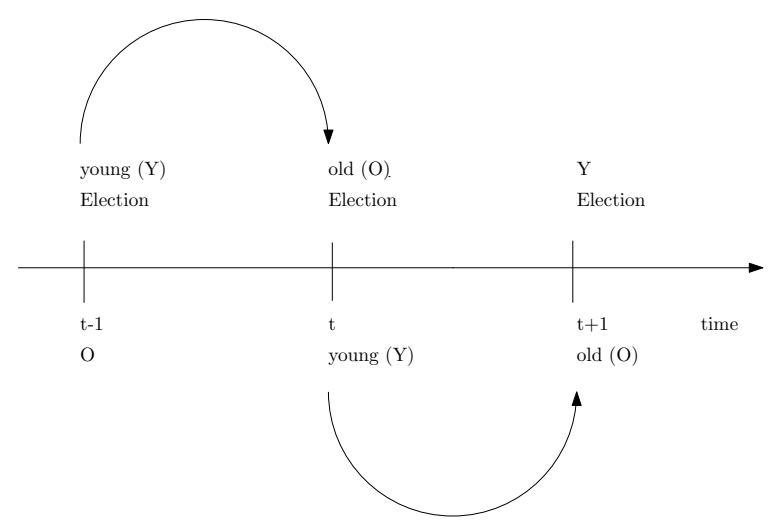

Figure A1: Incumbencies of lobbies overlap

Proof 1 Following the election rule, the voters re-elect an incumbent if they receive

$$
X\left\{\begin{array}{llrl}
=x\left(e_{Y}\right) & \text { if } & s_{O}=L \\
=x\left(e_{Y}\right)+x_{s_{O}}\left(e_{O}\right) & \text { if } & s_{O}=H
\end{array}\right.
$$

which is the payoff they receive if a good politician is in office, depending on the old lobby's type. Since the voters base their decision on their payoffs from the previous period, a bad politician who is eligible for re-election who supported an old low type lobby (i.e., chose to separate from the good types) in the previous period is immediately revealed as a bad politician and therefore will not be reelected.

Proof 2 If the old lobby in period 1 is a low type and the young lobby is a high type: Bad politicians receive $E+k$ in period 1 if they support both lobbies. This reveals them as bad politicians, which implies that they are not re-elected and hence, do not receive any payments in their second period. If bad politicians choose to support only the young lobby in period 1, i.e., if they choose to pool, they receive $E$ in period 1. In this case, bad politicians are re-elected and receive expected payments of $\beta E+\beta\left(2 k-a_{H}+\alpha\left(k-a_{L}\right)\right)$ in their second period. Hence, if the old lobby is a low type and the young lobby is a high type, then bad politicians pool if

$$
E+k \leq E+\beta E+\beta\left(2 k-a_{H}+\alpha\left(k-a_{L}\right)\right)
$$

or

$$
E \geq \frac{k}{\beta}-\left(2 k-a_{H}\right)-\alpha\left(k-a_{L}\right)
$$

If both lobbies in period 1 are low types: Bad politicians receive $k+k-a_{L}+E$ if they separate and an expected payoff of $E+\beta E+\beta\left(k+\alpha\left(k-a_{L}\right)\right)$ if they pool with good politicians. Hence, bad 
politicians pool if

$$
E+\beta E+\beta\left(k+\alpha\left(k-a_{L}\right)\right) \geq k+k-a_{L}+E
$$

or

$$
E \geq\left(\frac{1-\alpha \beta}{\beta}\right)\left(k-a_{L}\right)+k\left(\frac{1-\beta}{\beta}\right)
$$

Proof 3 If the old lobby in period 1 is a low type and the young lobby is a high type: The expected spillovers to the voters are $x+\beta 2 x$ if bad politicians pool. If bad politicians separate from good ones, the expected benefit is $\beta 2 x$. If both lobbies in period 1 are low types: The expected spillovers to the voters is $x$ if bad politicians pool. If bad politicians separate from good ones, the expected voter benefit is $\Pi x$. Hence, voter welfare increases if bad politicians choose to pool with good ones.

Proof 4 Good politicians support both lobby types if the expected voter welfare from doing that is higher than the expected voter welfare from supporting only young lobbies, i.e., if

$$
(1-\alpha)^{2} 2 x+\alpha(1-\alpha) 0+\alpha(1-\alpha) 2 x+\alpha^{2} 0 \geq x
$$

which can be simplified to the condition

$$
\frac{1}{2} \geq x
$$

Proof 5 Bad politicians pool with good ones if the expected payments they receive from pooling are larger than the expected payments if they separate. The expected payments from pooling are

$$
E+\alpha\left(k-a_{L}\right)+\beta k \alpha+\beta(1-\alpha)\left(2 k-a_{H}\right)+\beta \alpha\left(k-a_{L}\right)+\beta E
$$

And the expected payments from separating are given by

$$
E+\alpha\left(k-a_{L}\right)+k \alpha+(1-\alpha)\left(2 k-a_{H}\right)
$$

Hence, pooling is optimal if

$$
E \geq\left(\frac{1}{\beta}-2\right) \alpha k+\left(\frac{1}{\beta}-1\right)(1-\alpha)\left(2 k-a_{H}\right)+\alpha a_{L}
$$

Proof 6 As long as good politicians support old lobbies, the expected payoff of high type lobbies is positive. If good politicians do not support old lobbies, the expected payoff of high type lobbies becomes negative and they do not join the pool of potential lobbies.

Proof 7 Both pooling conditions of the baseline model are more restrictive than the pooling conditions of the extension of the model. Three cases are possible: 
(1) If the old lobby in period 1 is a low type and the young lobby is a high type and $\frac{1}{2}<\alpha \leq 1$, the pooling condition of the baseline model is more restrictive if

$$
\frac{k}{\beta}-\left(2 k-a_{H}\right)-\alpha\left(k-a_{L}\right)>\left(\frac{1}{\beta}-2\right) \alpha k+\left(\frac{1}{\beta}-1\right)(1-\alpha)\left(2 k-a_{H}\right)+\alpha a_{L}
$$

which is the case since the expression above can be simplified as

$$
a_{H}(\alpha \beta-\alpha+1)>k(1-\alpha-4 \beta-\alpha \beta)
$$

where the inequality has to hold because $a_{H}>k$ and $(\alpha \beta-\alpha+1)>(1-\alpha-4 \beta-\alpha \beta)$.

(2) If both lobbies are low types and $\frac{1}{2}<\alpha \leq 1$, the pooling condition of the baseline model is more restrictive if

$$
\left(\frac{1}{\beta}-\alpha\right)\left(k-a_{L}\right)+k\left(\frac{1}{\beta}-1\right)>\left(\frac{1}{\beta}-2\right) \alpha k+\left(\frac{1}{\beta}-1\right)(1-\alpha)\left(2 k-a_{H}\right)+\alpha a_{L}
$$

This expression can be simplified as follows

$$
\left(\frac{1}{\beta}-\alpha\right)\left(k-a_{L}\right)+\alpha\left(k-a_{L}\right)>(1-\alpha)\left(\frac{1}{\beta}-1\right)\left(k-a_{H}\right)
$$

The inequality holds because the left hand side of the equation is positive and the right hand side is negative.

(3) If both lobbies are low types and $\alpha=1$, the pooling condition of the baseline model is more restrictive if

$$
\left(\frac{1}{\beta}-\alpha\right)\left(k-a_{L}\right)+k\left(\frac{1}{\beta}-1\right)>k\left(\frac{1}{\beta}-2\right)+a_{L}
$$

which is the case since

$$
k>a_{L}
$$

Proof 8 The expected payoff to the voters is $x+\beta(1-\alpha) 2 x$ if bad politicians pool. If bad politicians separate from good ones, the expected payoff to the voters is $(1-\alpha) 2 x+\beta \Pi x+\beta(1-\Pi)(1-\alpha) 2 x$. As long as $\alpha<\frac{1}{2}$, without which pooling is automatic, the expected payoff if bad politicians pool is larger than the one if bad politicians separate from good ones. Hence, voter welfare increases if bad politicians choose to pool with good ones. 


\section{References}

Aidt, T.S. (2003). Redistribution and deadweight costs: the role of political competition. European Journal of Political Economy 19: 205-226.

Aidt, T.S., Hillman, A.L. (2008). Enduring Rents. European Journal of Political Economy 24: 545-553.

Aidt, T.S., Dutta, J. (2007). Policy myopia and economic growth. European Journal of Political Economy 23: 734-753.

Anderson, J.E. (1995). The Uruguay Round and welfare in some distorted agricultural economies. Journal of Development Economics 56: 393-410.

Becker, G. (1983). A Theory of Competition among Pressure Groups for Political Influence. Quarterly Journal of Economics 98: 371-400.

Begovic, B., Paunovic, M. (2011). Political support for enterprise restructuring and voting in Serbia. European Journal of Political Economy 27: 171-180.

Besley, T. (2006). Principled Agents? - The Political Economy of Good Government, first ed. Oxford University Press, Oxford.

Besley, T., Case, A. (1995). Does Political Accountability Affect Economic Policy Choices? Evidence from Gubernatorial Term Limits. Quarterly Journal of Economics 110: 769-798.

Bhimani, A., Hausken, K., Ncube, M. (2010). Agent Takeover Risk of Principal in Outsourcing Relationships. Global Business and Economics Review 12(4): 329-340.

Cassing, J.H. (1991). Changes in Trade-Policy Regimes. In: Hillman, A.L. Markets and Politicians - Politicized Economic Choice. Kluwer Academic Publishers, Norwell: 307-318.

Coate, S., Morris, S. (1999). Policy Persistence. American Economic Review 89: 1327-1336.

Crew, M.A., Twight, C. (1990). On the Efficiency of Law: A Public Choice Perspective. Public Choice 66: 15-36.

Crew, M.A., Rowley, C.K. (1988). Toward a Public Choice Theory of Monopoly Regulation. Public Choice 57: 49-67.

Friedrich, S. (2011). Policy Persistence and Rent Extraction, Ifo Working Paper 110.

Gersbach, H. (2004). Competition of Politicians for Incentive Contracts and Elections. Public Choice 121: 157-177. 
Grossman, G.M., Helpman, E. (1994). Protection for Sale. American Economic Review 84: 833-850.

Hillman, A.L. (1982). Declining Industries and Political-Support Protectionist Motives. American Economic Review 72: 1180-1187.

Le Breton, M., Salanie, F. (2003). Lobbying under Political Uncertainty. Journal of Public Economics 87: 2589-2610.

Mishan, E.J., Quah, E. (2007). Cost-benefit analysis, fifth ed. Routledge, New York.

Olson, M. (1982). The Rise and Decline of Nations, first ed. Yale University Press, Yale.

Peltzman, S. (1976). Towards a More General Theory of Regulation. Journal of Law and Economics 19: $211-240$.

Potters, J., Van Winden, F. (1992). Lobbying and asymmetric information. Public Choice 74: 269-292.

Putnam, R.D. (1994). Making Democracy Work: Civic Traditions in Modern Italy, first ed. Princeton University Press, Princeton.

Tokarick, S. (2005). Who bears the cost of agricultural support in OECD countries?. The World Economy 28: 573-593.

Tullock, G. (1989). The Economics of Special Privilege and Rent Seeking. Boston: Kluwer-Nijhoff.

Tullock, G. (1983). Economics of Income Redistribution. Boston: Kluwer-Nijhoff. 


\section{Acknowledgments}

I would like to thank Christopher J. Ellis, Arye Hillman, Panu Poutvaara, the participants of the Silvaplana Workshop of Political Economy, and the participants of the annual meeting of the Association for Public Economic Theory for helpful comments and suggestions. I am also very grateful to three anonymous referees who provided many helpful comments. Any errors are my own. ${ }^{25}$

\footnotetext{
${ }^{25}$ An earlier version of this paper was published in the Ifo Working Paper Series (Friedrich 2011).
} 